\title{
Familiáris myelodysplasiás szindróma és akut myeloid leukaemia klinikai és genetikai háttere
}

\author{
Király Péter Attila dr. ${ }^{1}$ - Kállay Krisztián dr. ${ }^{2}$ \\ Marosvári Dóra dr. ${ }^{1}$ - Benyó Gábor dr. ${ }^{2}$ - Szőke Anita dr. ${ }^{3}$ \\ Csomor Judit dr. ${ }^{1}$ - Bödör Csaba dr. ${ }^{1}$ \\ ${ }^{1}$ MTA-SE Lendület Molekuláris Onkohematológia Munkacsoport, Semmelweis Egyetem, \\ I. Patológiai és Kísérleti Rákkutató Intézet, Budapest \\ ${ }^{2}$ Egyesített Szent István és Szent László Kórház, Gyermekhematológiai és Őssejttranszplantációs Osztály, \\ Budapest \\ ${ }^{3}$ Szegedi Tudományegyetem, Általános Orvostudományi Kar, Belgyógyászati Klinika, Szeged
}

\begin{abstract}
A myelodysplasiás szindróma és az akut myeloid leukaemia döntően sporadikus megbetegedések, azonban a fiatalkorban előforduló, illetve a családi halmozódást mutató esetekról egyre gyakrabban derül ki, hogy valójában örökletes kórképek, amelyek hátterében a myeloid vérképzést szabályozó faktorok autoszomális domináns mutációi állnak. Ezen örökletes mutációk jellegzetes szindrómákat hoznak létre, amelyek fokozott kockázattal járnak myelodysplasia és akut leukaemia kialakulására (prediszpozíciós szindrómák). Jelenleg négy ilyen szindróma ismert: (1) a CEBPA-, valamint a (2) GATA2-mutációt hordozó familiáris myelodysplasia/akut leukaemia, (3) a familiáris vérlemezke-funkciózavar talaján kialakuló myelodysplasia a $R U N X 1$ gén mutációjával és (4) a telomerázbiológiát érintő kórképek, amelyek a TERT vagy TERC gének mutációival jellemezhetók. A közelmúltban derült ki, hogy az ANKRD26, ETV6, SRP72 és DDX41 gének mutációi szintén szerepet játszhatnak familiáris myeloid kórképek kialakításában. Jelen öszszefoglaló közlemény célja e különleges betegségcsoportra való figyelemfelhívás, valamint e kórképek genetikai és klinikai hátterének ismertetése. Orv. Hetil., 2016, 157(8), 283-289.
\end{abstract}

Kulcsszavak: germline mutáció, familiáris leukaemia, CEBPA, GATA2, RUNX1, MDS

\section{Clinical and genetic background of familial myelodysplasia and acute myeloid leukemia}

Myelodysplastic syndrome and acute myeloid leukaemia are mainly sporadic diseases, however, rare familial cases exist. These disorders are considered rare, but are likely to be more common than currently appreciated, and are characterized by the autosomal dominant mutations of hematopoietic transcription factors. These syndromes have typical phenotypic features and are associated with an increased risk for developing overt malignancy. Currently, four recognized syndromes could be separated: familial acute myeloid leukemia with mutated CEBPA, familial myelodysplastic syndrome/acute myeloid leukemia with mutated GATA2, familial platelet disorder with propensity to myeloid malignancy with RUNXI mutations, and telomere biology disorders due to mutations of TERC or TERT. Furthermore, there are new, emerging syndromes associated with germline mutations in novel genes including ANKRD26, ETV6, SRP72 or DDX41. This review will discuss the current understanding of the genetic basis and clinical presentation of familial leukemia and myelodysplasia.

Keywords: germline mutation, familial leukemia, CEBPA, GATA2, RUNX1, MDS

Király, P. A., Kállay, K., Marosvári, D., Benyó, G., Szőke, A., Csomor, J., Bödör, Cs. [Clinical and genetic background of familial myelodysplasia and acute myeloid leukemia]. Orv. Hetil., 2016, 157(8), 283-289.

(Beérkezett: 2015. december 8.; elfogadva: 2016. január 7.) 


\section{Rövidítések}

$\mathrm{AML}=$ akut myeloid leukaemia; $\mathrm{CBF}=$ core binding factor; $C D C 25 c$ = sejtciklus szabályozásában részt vevô gén; CEBPA = CCAAT/enhancer binding protein alpha; FA = Fanconi-anaemia; FPD = familial platelet disorder; GATA2 gén = cinkujjmotívumot tartalmazó transzkripciós faktor; MDS = myelodysplasiás szindróma; RUNXl = CBF transzkripciós komplex DNS-kötő eleme; TBD = telomerase biology disorders; TERT és TERC $=$ a telomeráz RNS-komponensét és reverz transzkriptáz enzimét kódoló gének; THC2 $=2$-es típusú familiáris thrombocytopenia

A myelodysplasiás szindróma (MDS) és az akut myeloid leukaemia (AML) döntően sporadikus megbetegedések, azonban előfordulhatnak familiáris, öröklődő szindróma formájában is (familiáris MDS/AML prediszpozíciós szindrómák). A familiáris daganatokat az egyszerú, úgynevezett családi halmozódást mutató tumoroktól az különíti el, hogy a hátterükben a myeloid érésben részt vevő transzkripciós faktorok és egyéb szabályozó gének örökletes mutációi állnak. Korábban ezeket a kórképeket irodalmi ritkaságnak tartották, azonban napjaink egyre bővülő esettanulmányai alapján feltételezhető, hogy ezek előfordulását alábecsüljük [1]. Számos gén érintettségét írták már le, amelyek mutációi és az általuk kiváltott jellegzetes kórkép (hematológiai és nem hematológiai tünetek egyaránt) alapján a betegségek csoportosíthatók. A familiáris MDS/AML prediszpozíciós szindrómák az egész élethosszon keresztül fokozott MDS-AML rizikóval járnak és jellegzetes klinikai kép formájában nyilvánulnak meg. Jelenleg négy nagyobb csoportot különböztetünk meg. Idetartoznak a CEBPAmutációt hordozó familiáris AML [2], a GATA2 gén mutációjával járó familiáris MDS/AML [3], a familiáris vérlemezke-funkciózavar (familial platelet disorder FPD) talaján kialakuló MDS/AML a RUNXI gén mutációjával [4], az örökletes csontvelő-kimerüléssel járó kórképek és a telomerázbiológiát érintő kórképek, többek között a TERT vagy TERC gén mutációival [5], s újabban megismert gének (ANKRD26, ETV6, SRP72 és $D D X 41)$ is állhatnak familiáris MDS/AML hátterében [6-9].

A familiáris MDS/AML prediszpozíciós szindrómák klinikai felismerése kihívást jelentő feladat, aminek alapja a rendkívül részletes anamnézis, amely kiterjed a beteg teljes korábbi kórtörténetének feltárására, valamint a közvetlen rokonok betegségeire is. Familiáris eredetre hívhatja fel a figyelmet, ha a betegség családi halmozódást mutat (legalább két érintett személy a családban), a fiatal életkor $(<45)$, vérlemezkeszám-eltérések, gyakori visszatérő infekciók és a lymphoedema. Ezekben az esetekben indokolt lehet a genetikai vizsgálat, ami a fent említett gének mutációinak keresését jelenti. Érdemes továbbá az FPD-AML hátterében álló genetikai eltéréseket (RUNXI, ANKRD26, ETV6) szúrni azokban a betegekben is, akikben terápiarefrakter thrombocytopenia áll fenn, amit kezdetben autoimmun eredetúnek gon- doltak [10]. A familiáris MDS/AML felismerésének kiemelt jelentősége van a csontvelö-transzplantáció tervezésekor is, a mutációt hordozó lehetséges rokon donorok kizárása kapcsán.

Jelen összefoglaló közlemény e különleges betegségcsoportra való figyelemfelhívás a familiáris MDS/AML hátterében álló genetikai, valamint legfontosabb klinikai eltérések ismertetése által.

\section{$C E B P A$-mutációt hordozó familiáris $\mathrm{AML}$}

Az úgynevezett „tiszta” familiáris AML hátterében a $C E B P A$ gén autoszomális domináns módon öröklődő mutációi állnak. A kórkép jellegzetesen fiatalkorban (249 év) jelenik meg, megelőző hematológiai tünetek és megbetegedések nélkül, és szinte teljes penetranciát mutat, azaz a mutáció megléte szinte százszázalékos valószínûséggel AML-t okoz $[2,11]$. A CEBPA gén (CCAAT/ enhancer binding protein alpha) a 19-es kromoszómán elhelyezkedő leucincipzár-motívumot tartalmazó transzkripciós faktor, amely a myeloid sejtek érésében játszik szerepet [12]. A csíravonalbeli mutációk döntóen a gén 5 ' szakaszára (úgynevezett N-terminális régió) lokalizálódó frameshift mutációk, amelyek egy rövidebb fehérjeformát eredményeznek, ami a normális allélról átíródó termék múködését gátolja (úgynevezett domináns negatív hatás) [13]. A kórkép előrehaladtával jellemzően az ép allélon, a gén 3 ' végén (úgynevezett $\mathrm{C}$-terminális régió) is megjelenik egy kooperáló szomatikus mutáció (dupla CEBPA-mutáció, illetve biallélikus CEBPA-mutáció) (1. ábra) [14]. A CEBPA gén sporadikus AML-ben is hordozhat mutációkat az esetek mintegy 10\%-ában. Sporadikusan is előfordulhat mono- és biallélikus formában is, amelyek közül az utóbbi kedvező klinikai lefolyással társul és önálló entitásként szerepel a legújabb WHO-klaszszifikációban (AML biallélikus CEBPA-mutációval) [15].

A csíravonali CEBPA-mutációt hordozó esetek klinikai megjelenés szempontjából nem különböznek a CEBPA-mutációt nem hordozó, normális karyotypusú AML-től, ellenben kedvezőbb kórlefolyást mutatnak [16]. A normális karyotypusú AML mintegy 18\%-a hordoz CEBPA-mutációt. Egy tanulmányban leírták, hogy a sporadikusnak tûnő $C E B P A$-mutációk 10\%-a alaposabb vizsgálat után valójában örökletesnek bizonyult [14]. Ebből kifolyólag a fiatalkori esetekben (<45 év) fontos lehet a részletes családi anamnézis feltárása és a mutáció csíravonalbeli eredetének tisztázása. A betegség kezelésében fontos szerepe van a csontvelö-transzplantációnak, bár a betegség viszonylagosan jobb prognózisa miatt ez egyéni elbírálás alapján dönthető el [17]. Érdekes megfigyelés, hogy egyes esetekben a betegség relapsusakor nem ugyanazon szomatikus mutációt hordozó klón jelenik meg újra, hanem egy új, a korábbi vizsgálatok idejében még nem kimutatható klón. Ezek alapján az is felmerül, hogy a visszatérő betegség nem is hagyományos értelemben vett relapsus, hanem egy második de novo AML [18]. 


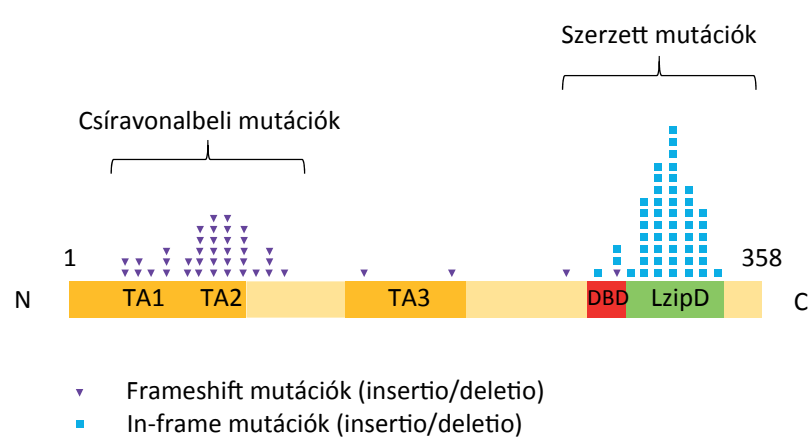

1. ábra

A CEBPA fehérje szerkezete. A CEBPA gén egy leucincipzáras transzkripciós faktor. A fehérje fó alegységei a dimerizációért és DNS-kötésért felelős domének. A gén $\mathrm{N}$ - és $\mathrm{C}$-terminális régióját érintő mutációk helyei a transzaktivációs és leucincipzár-motívumokban helyezkednek el

DBD = DNS-kötő domén; LzipD = leucincipzárdomén; TA = transzaktivációs domén;

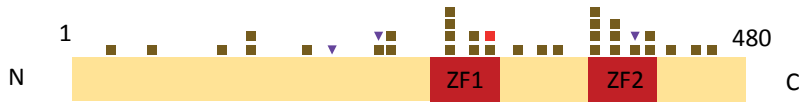

V Frameshift mutációk (insertio/deletio)

- Pontmutáció

- Stopkodont eredményező mutáció

A GATA2 fehérje szerkezete. A cinkujjas transzkripciós faktor a GATA-szekvenciaelemeket ismeri fel célgénjeinek promóter szakaszában. A génben leírt mutációk a két cinkujjrégiót érintik leggyakrabban

$\mathrm{ZF}=$ cinkujjmotívum
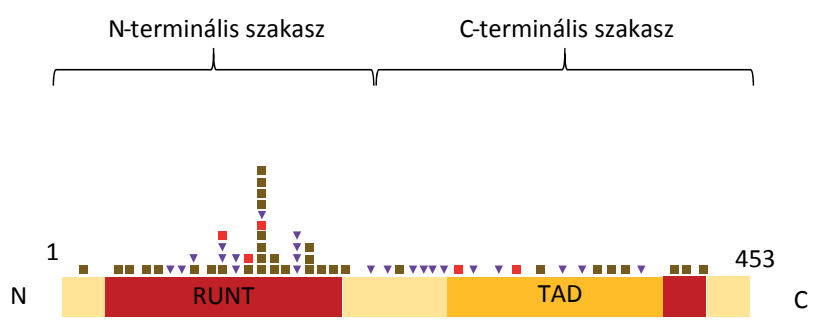

- Frameshift mutációk (insertio/deletio)

- Pontmutáció

- Stopkodont eredményező mutáció

2. ábra

A RUNXI fehérje szerkezete. A $R U N X I$ vagy más néven core binding factor egy heterodimert képező transzkripciós faktor, amely számos gén promóter régiójához képes kötődni. A génben eddig leírt mutációk a DNS-kötésért felelős RUNT doménben fordulnak elő leginkább

RUNT $=$ RUNT domén; TAD = transzaktivációs domén

\section{Familiáris vérlemezke-funkciózavar talaján kialakuló MDS/AML (FPD-AML)}

Az FPD-AML a legjobban karakterizált örökletes familiáris MDS/AML prediszpozíciós szindróma [4]. Az első jól dokumentált familiáris hematológiai kórkép, napjainkig több mint 30 családfát tártak fel [1, 19]. A kórkép jellegzetessége a változó fokú vérzészavar, amely rejtve is maradhat, de meg is nyilvánulhat thrombocytaszám-eltérésben és enyhe-középsúlyos vérzékenység formájában is [20]. A vérlemezke-funkciózavarból kifejlődő MDS/ AML rizikója mintegy $40 \%$ az egész élethossz alatt [21]. A kórkép hátterében a $R U N X I$ gén autoszomális domi-

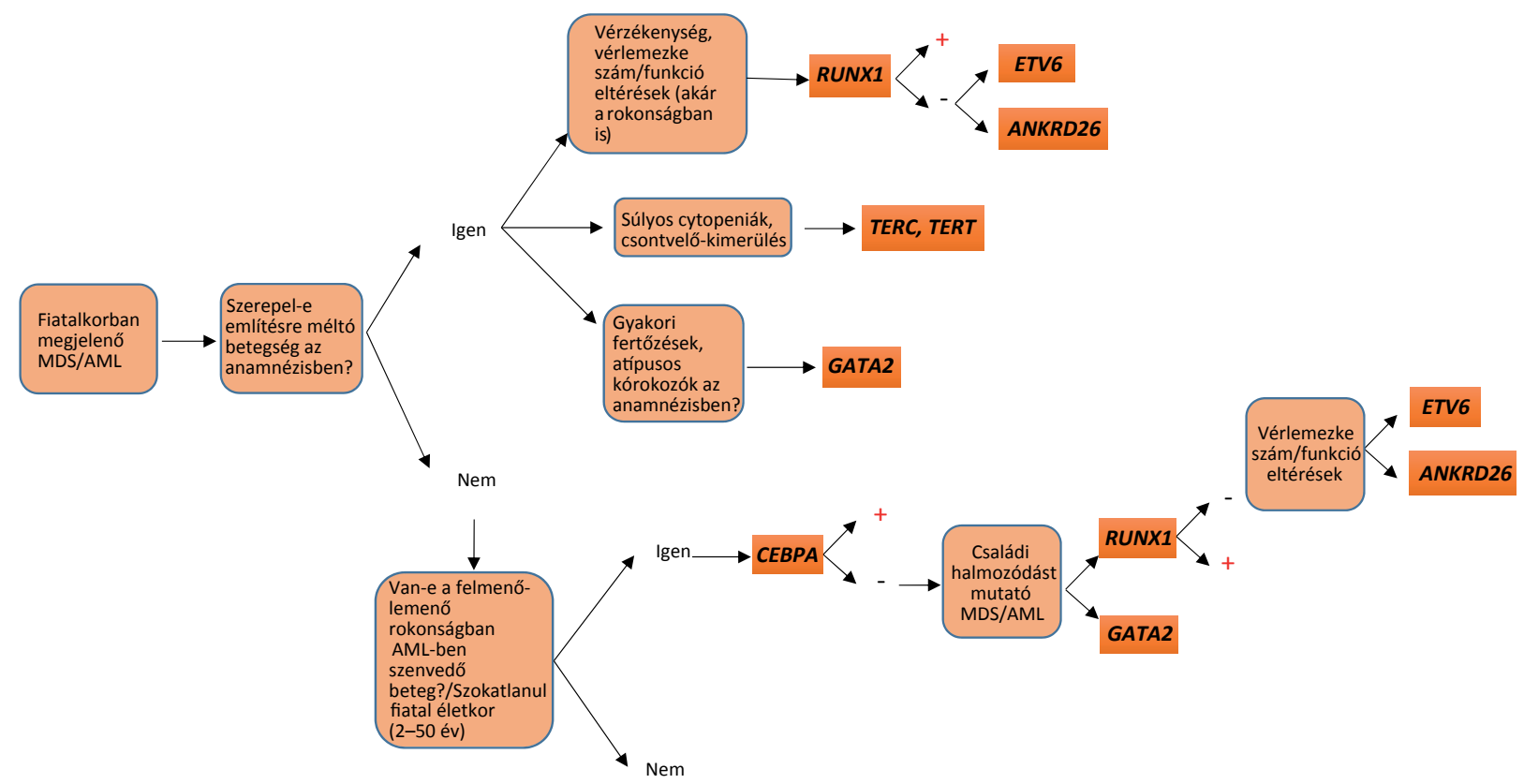

\begin{tabular}{l|l} 
4. ábra & Diagnosztikus algoritmus a tünetek alapján történő genetikai vizsgálathoz
\end{tabular}

Az ábrán egy lehetséges diagnosztikus algoritmus látható, amely segíti a csíravonalbeli mutációk azonosítását és a familiáris eredet tisztázását a legygyakrabban előforduló klinikai tünetek alapján (Bessler et al., Best Pract. and Res. Clin. Haematol. 2015 alapján módosítva) 
náns módon öröklődő mutációi állnak. A RUNXI a core binding factor (CBF) transzkripciós komplex DNS-kötő eleme, amely a haemopoesis fontos szabályozója. A mutációk döntő többségben a nagyfokú konzerváltságot mutató RUNT doménben helyezkednek el (2. ábra). Az eddig leírt mutációk lehetnek missense, nonsense, indel variánsok, de leírtak már congenitalis transzlokációt is [22]. Mivel a RUNXI csíravonali mutációt hordozó egyének klinikai képe igen változatos, felvetődött, hogy a gén mutációja önmagában nem elégséges az MDS/ AML kialakulásához. Jelenleg sem ismert a pontos mechanizmus, bár több kooperáló mutációt leírtak már, ami a betegség progressziójához társul. Gyakori szomatikus eltérés FPD-AML-ben a második, ép $R U N X I$ allél szerzett mutációja a tumorsejtekben. RUNX1-mutáció sporadikus AML-ben is előfordulhat, de ezekben az esetekben a mutáció mindig monoallélikus. Így biallélikus $R U N X 1$-mutáció esetén vagy 50\%-nál magasabb allélfrekvencia esetén feltehetően familiáris $R U N X 1$-mutációról van szó, a második allél szomatikus érintettségével [23]. Egy másik jelentős, a közelmúltban leírt kooperációs mechanizmus a CDC25c gén szomatikus mutációja. A CDC25c a sejtciklus szabályozásában részt vevő gén, amely a vizsgált esetek 53\%-ában jelen volt, korai, úgynevezett driver mutáció formájában [24].

Ha a betegség a vérlemezke-funkciózavar stádiumában kerül felismerésre és bebizonyosodik a háttérben lévő $R U N X 1$-mutáció, érdemes a betegeket háromhavonta hematológiai centrumban követni. A mutáció ki- mutatásának pillanatában érdemes a HLA-tipizálást elvégeztetni, és a rokonság körében is meg kell határozni a $R U N X 1$-mutációs státuszt. Azok a testvérek/rokonok, akik szintén hordozzák a mutáns allélt, nem lehetnek később őssejtdonorok, illetve maguk is potenciálisan betegnek tekintendők. Ha a betegnél MDS/AML tünetei jelentkeznek, konszolidációs terápiaként mindenképpen megfontolandó az ôssejt-transzplantáció, hiszen így van csak esély a mutáns allél teljes eliminálására a csontvelőből [21].

\section{GATA2-mutációt hordozó familiáris MDS/AML}

A GATA2 gén mutációinak első leírására is familiárisan halmozódó leukaemia kapcsán került sor [3]. Később azonban kiderült, hogy a GATA2 mutációi több változatos immunológiai kórkép kialakításáért is felelősek. Ezek az Emberger-szindróma [25], a MonoMAC- [26] és DCML- [27] szindrómák. E kórképek jellegzetes tünetei a lymphoedema, a monocyták, dendritikus sejtek, B-sejtek és NK-sejtek hiánya. Következményesen gyakoriak az atípusos infekciók, rekurrens vírusinfekciók, alveolaris proteinosis (1. táblázat) [25-27]. Az MDS/AML kialakulásának penetranciája igen magas (70\%), általában fiatalkorban nyilvánul meg (10-48 év között) [3]. A GATA2 gén egy cinkujjmotívumot tartalmazó transzkripciós faktor, amely a haemopoesis szinte valamennyi sejtjének érésében és endothelbillentyưk formálásában is

1. táblázat |A legfontosabb familiáris MDS/AML prediszpozíciós szindrómák klinikai képe az érintett gén feltüntetésével

\begin{tabular}{ll}
\hline Valószínű kórkép & Klinikai megjelenés \\
\hline Úgynevezett „tiszta” familiáris AML & Fiatalkori akut myeloid leukaemia (szokatlanul fiatal életkor [2-59 év]) $\quad$ CEBPA \\
& Családi halmozódás (felmenő és oldalági rokonságban előfordult AML) \\
& Megelőző hematológiai tünetek hiányoznak \\
& Magasabb hemoglobin, alacsonyabb vérlemezkeszám \\
\hline Familiáris vérlemezke-funkciózavar & Változatos súlyosságú vérzékenység \\
(FPD) talaján kialakuló AML & Vérzékenység és MDS/AML előfordulása a felmenörokonság körében \\
& Monocytopaenia \\
& Atípusos mycobacterium infekciók \\
& Szemölcsök és rekurrens vírusfertózések \\
\hline
\end{tabular}

MonoMAC, Emberger és DCML Rekurrens felső légúti és húgyútfertőzések GATA2

Alveolaris proteinosis

Dendritikus sejt, monocyta, B-sejt és NK-sejt deficientia/hiány

Generalizált lymphoedema

HPV-okozta fertózések gyakori fellángolása és intraepithelialis neoplasia

Örökletes csontvelö-kimerülési szindrómák, Fanconi-anaemia, Dyskeratosis congenita-TBD
Csontvelö-kimerülés (gyakran megelőző tünetek nélkül, inkább gyerekkorban, de akár fiatal felnőttekben is)

Citotoxikus ágensekkel való érintkezés kizárható

Jellegzetes fizikai eltérések (café-au-lait foltok, körömdisztráfia hipopigmentáció, szív- és vázizomfejlődési rendellenességek, tüdőfibrosis, alacsony növés, radiológiai eltérések) 
szerepet játszik [28]. A génben eddig leírt mutációk döntően a két cinkujjdoménben fordulnak elő (3. ábra). Érdekes, hogy a heterogén klinikai megjelenés hátterében ugyanazon pontmutáció állhat, így ha a visszatérő atípusos infekciók és a családi halmozódás felveti a gyanút, mindenképpen érdemes a GATA2 gén genetikai vizsgálatát elvégeztetni [29]. Az MDS/AML-be történő transzformáció mechanizmusa a csíravonali GATA2-mutációt hordozó esetekben még nem teljesen tisztázott. Munkacsoportunk a transzformáció során fontos kooperáló mechanizmusként a 7-es kromoszóma monoszómiáját, illetve az ASXLI nevú gén szomatikus mutációját írta le [30], amely megfigyelést azóta egy másik munkacsoport is megerősítette [31]. A betegség kezelését illetően az irányelvek nem térnek el a sporadikus esetek kezelésétől. A fiatal életkor és a mutáns allél miatti gyakori kiújulási hajlam miatt ajánlott az allogén csontvelő-átültetés megfontolása, természetesen a szóba kerülő rokon donorok előzetes genetikai szűrésével [10].

A sporadikus GATA2-mutációt hordozó MDS/AML esetek klinikai képe nem mutat jellegzetességet. Leggyakrabban normális karyotypus mellett fordul elő, azonban szignifikáns gyakorisággal fordul elő együttesen CEBPA-mutációval. Ezekben az esetekben, különösen a dupla típusú $C E B P A$-mutáció esetén, nem befolyásolja a kedvező kórlefolyást [32].

\section{Örökletes csontvelő-kimerüléssel járó kórképek és a telomerázbiológiát érintő kórképek a TERT és TERC gén mutációival}

Az örökletes MDS/AML prediszpozíciós szindrómák legösszetettebb csoportját képezik ezek a betegségek, amelyek részletes tárgyalása túlmutat ezen összefoglaló keretein. A csoportba tartozó betegségek részben már gyermekkorban megjelenhetnek, különböző fejlődési rendellenességek képében, ám felnőttkorban kialakuló csontvelői elégtelenség és MDS is lehet az első tünet (1. táblázat) [5]. Az örökletes csontvelő-kimerüléssel járó kórképek közül a leggyakoribb a Fanconi-anaemia (FA). Az FA már korai gyermekkorban megnyilvánulhat, jellegzetes radiológiai eltérések (kézfejröntgen: orsócsonthiány, gerincet érintő rendellenességek), zsigeri szervek eltérései (szív, vese, endokrin szervek) és egyéb tünetek („café-au-lait” foltok) kíséretében. Nem ritka azonban az sem, hogy a betegség első tünete a fiatal felnőttkorban megnyilvánuló MDS/AML [33].

A telomerázbiológiát érintő kórképek (telomerase biology disorders - TBD) azon betegségek gyüjtőcsoportja, amelyeket a telomérek fenntartásáért felelős gének mutációi okoznak [34]. A telomérek a kromoszómák végein elhelyezkedő régiók, amelyek a sejtek osztódásainak számát és így az élettartamukat befolyásolják [35]. A telomérek funkciója kiemelkedően fontos a rendszeresen osztódó szövetekben, így a csontvelőben is, és idő előtti rövidülésük a haemopoeticus őssejtek apoptózisát okozza [34]. Több gént is leírtak már, amelyek mutációja kapcsolatba hozható TBD kialakulásával [36]. A $D K C 1$ gén mutációja által létrehozott klasszikus kórkép a dyskeratosis congenita, amelynek diagnosztikus triásza a hairy leukoplakia, körömdystrophia és reticularis pigmentáció. A kórkép fokozott rizikóval jár több malignus betegségre, köztük az MDS/AML-re is fiatalkorban [37]. A TERT és TERC gének a telomeráz RNSkomponensét és reverz transzkriptáz enzimét kódolják. A két gén mutációi autoszomális domináns öröklésmenetet mutató familiáris MDS-t hoznak létre, a kórkép változó penetranciájú. Az érintettekben a hematológiai betegségeken túl kialakulhat idiopathiás tüdőfibrosis, májcirrhosis, valamint fej-nyaki tumorok is [38].

\section{Újonnan azonosított hajlamosító gének és szindrómák}

Jelen ismereteink szerint a familiáris esetek mintegy $40 \%$ ához tudunk rendelni valamely szabályozó fehérjében megjelenő csíravonalbeli mutációt. Azon esetek egy részében, ahol a karakterisztikus klinikai kép ellenére sem sikerült a fent említett genetikai eltéréseket igazolni, az új generációs szekvenálási technológiák további génekben azonosítottak mutációkat. Az ilyen familiáris MDS/AML és aplasztikus anaemia esetek hátterében azonosították az $S R P 72$ gén mutációit, ami a ribonukleoprotein részeként a fehérjék endoplazmás reticulum felé történő transzportját szabályozza [6]. Azokban a családokban, ahol az FPD/AML hátterében nem sikerült az ismert RUNXI gén mutációit kimutatni, a közelmúltban fedezték fel az ANKRD26 és az ETV6 gének csíravonali mutációit $[7,9] . \mathrm{Az} A N K R D 26$ egy ankirin repeat doméneket tartalmazó fehérje, amelynek fiziológiás funkciója és a betegségben játszott szerepe jelenleg még nem ismert. Az ANKRD26 mutációit az autoszomális domináns öröklődésű 2. típusú familiáris thrombocytopenia (THC2) hátterében írták le korábban, amely betegség fokozott MDS/AML kockázatával jár együtt $[9,39]$. Az ETV6 egy transzkripciós faktor, amelynek két fontos doménje van, az N-terminális a protein-protein interakcióért felelős, a C-terminális pedig a DNS-kötésért. A gén funkcióját vizsgáló kísérletek során azt találták, hogy szerepet játszik a haematopoesisben és kapillárishálózatok kifejlődésében is. A gén mutációit egy kiterjesztett familiáris vizsgálat során leírták olyan családokban, ahol visszatérően megjelent a thrombocytopeniás jelleg és változatos daganatféleségek fordultak elő fiatal életkorban $[7,40]$. Ha a RUNXI gén szekvenálása negatív eredményt hoz, de a klinikai gyanú fennmarad familiáris FPD-AML irányában, érdemes ezen gének vizsgálatát is elvégezni. Az újonnan felfedezett gének csoportja egyre bővülő tendenciát mutat. A legújabb kandidáns gén, amelynek mutációját több familiáris MDS/AML-ben szenvedő családban is megtalálták, a $D D X 41$. A gén sporadikus MDS/AML-ben is előfordul, azonban familiáris halmozódás hátterében 
frissen került felfedezésre. A $D D X 41$ mutációja hibás splicinghoz és károsodott mRNS-processzálódáshoz vezet $[8]$.

\section{Következtetések}

A familiáris MDS/AML eseteket korábban ritkán előforduló entitásnak gondolták, azonban napjainkban egyre több családi halmozódást mutató eset hátterében derül fény valamely transzkripciós faktor vagy egyéb szabályozó molekula öröklődő mutációjára. Mára az eddig feltárt esetek mintegy felében ismert már hajlamosító csíravonali eltérés, azonban a mutációt hordozó egyénekben változatos penetranciával jelenik meg a malignitás. Ez azt támasztja alá, hogy a hajlamosító csíravonali mutáció mellett több szerzett, szomatikus genetikai eltérés szükséges a malignitás megjelenéséhez. Jelenleg nem, vagy csak igen ritkán történik genetikai vizsgálat a fiatalkori vagy családi halmozódást mutató esetekben. A familiáris MDS/AML prediszpozíciós szindrómák korai felismerésének jelentősége a transzplantáció tervezése, donorszelekció (mutációt hordozó rokonok kizárása) és a mutációt hordozó, de tünetmentes egyének monitorozásában van [41]. A mutációs státusz ismeretében érdemes a hordozó egyéneknél csontvelö-biopsziát végezni, majd ezt követően a beteget szorosan követni és háromhavonta hematológiai kontrollvizsgálatot végezni. Ha a vérkép bármilyen mennyiségi vagy minőségi eltérést mutat, a vizsgálatot 1-2 hét elteltével meg kell ismételni, és ha továbbra is fennáll, csontvelő-biopsziát kell végezni. Minden esetben szem előtt kell tartani, hogy a rokontól kapott vérképző őssejt transzplantációja a mutáns allél visszaadását jelentheti $[10,42,43]$. Azokban az esetekben, amikor a rokonság körében a mutáns allélt nem hordozó rokon szóba jön mint donor, a kezelőorvosnak kell számba vennie a lehetőségeket, a transzplantáció sürgősségét, illetve a HLA-identikus idegen donorok lehetőségét [1].

A vérképző őssejt transzplantációjának eredményei világszerte javulnak, különösen igaz ez a fiatalkorban elvégzett beavatkozásokra. A korábban semmilyen kezelést nem kapott, úgynevezett kemoterápia-naiv betegek csoportja különösen jó túlélésú. Nonmalignus gyermek betegeknél a gyógyulási arány akár 90\% felett is lehet. Mindezek alapján megfontolandó a nagy penetranciájú, akár 70-100\%-os eséllyel malignitást okozó mutációt hordozó betegek „upfront” transzplantációja még a betegség kialakulása előtt.

Célszerû lenne egy egységes algoritmus alapján bevezetni a klinikai gyakorlatba a genetikai vizsgálatok elvégzését a familiáris eredet gyanúja esetén. A 4. ábrán egy javasolt diagnosztikus algoritmust mutatunk be ezen kórképek és genetikai tesztek között való tájékozódás segítésére (Bessler et al., Best Pract. and Res. Clin. Haematol. 2015 alapján). Mára munkacsoportunk beállította a fent említett kórképekben leggyakrabban előforduló mutációk (CEBPA, GATA, RUNX1, ETV6, ANKRD26,
SRP72, DDX41) vizsgálatát célzó diagnosztikus eljárásokat, és ezek már elérhetők a magyar hematológusközösség és a betegek számára.

A familiáris MDS/AML esetek kiváló modellként szolgálnak a daganatok kialakulásának és progressziójának jobb megértéséhez. Az itt megismert genetikai eltérések és kooperáló mechanizmusok gyakran jelentőséggel bírnak a sporadikus MDS/AML terén is.

Anyagi támogatás: A közlemény az Országos Tudományos Kutatási Alapprogramok - OTKA (OTKAPD108805) -, valamint az MTA Lendület program támogatásával készült.

Szerzôi munkamegosztás: Az összefoglaló közlemény megírásában, valamint az előzetes irodalmi adatok feldolgozásában minden szerző részt vett. A cikk végleges változatát valamennyi szerző elolvasta és jóváhagyta.

Érdekeltségek: A szerzőknek nincsenek érdekeltségeik.

\section{Irodalom}

[1] Nickels, E. M., Soodalter, J., Churpek, J. E., et al.: Recognizing familial myeloid leukemia in adults. Ther. Adv. Hematol., 2013, $4(4), 254-269$

[2] Smith, M. L., Cavenagh, J. D., Lister, T. A., et al.: Mutation of CEBPA in familial acute myeloid leukemia. N. Engl. J. Med., 2004, 351(23), 2403-2407.

[3] Hahn, C. N., Chong, C. E., Carmichael, C. L., et al.: Heritable GATA2 mutations associated with familial myelodysplastic syndrome and acute myeloid leukemia. Nat. Genet., 2011, 43(10), 1012-1017.

[4] Song, W. J., Sullivan, M. G., Legare, R. D., et al.: Haploinsufficiency of CBFA2 causes familial thrombocytopenia with propensity to develop acute myelogenous leukaemia. Nat. Genet., 1999, 23(2), 166-175.

[5] Dokal, I., Vulliamy, T.: Inherited bone marrow failure syndromes. Haematologica, 2010, 95(8), 1236-1240.

[6] Kirwan, M., Walne, A. J., Plagnol, V., et al.: Exome sequencing identifies autosomal-dominant SRP72 mutations associated with familial aplasia and myelodysplasia. Am. J. Hum. Genet., 2012, 90(5), 888-892.

[7] Zhang, M. Y., Churpek, J. E., Keel, S. B., et al.: Germline ETV6 mutations in familial thrombocytopenia and hematologic malignancy. Nat. Genet., 2015, 47(2), 180-185.

[8] Polprasert, C., Schulze, I., Sekeres, M. A., et al.: Inherited and somatic defects in DDX41 in myeloid neoplasms. Cancer Cell, $2015,27(5), 658-670$

[9] Pippucci, T., Savoia, A., Perrotta, S., et al.: Mutations in the 5' UTR of ANKRD26, the ankirin repeat domain 26 gene, cause an autosomal-dominant form of inherited thrombocytopenia, THC2. Am. J. Hum. Genet., 2011, 88(1), 115-120.

[10] Godley, L. A.: Inherited predisposition to acute myeloid leukemia. Semin. Hematol., 2014, 51(4), 306-321.

[11] Owen, C., Barnett, M., Fitzgibbon, J.: Familial myelodysplasia and acute myeloid leukaemia - a review. Br. J. Haematol., 2008, $140(2), 123-132$.

[12] Antonson, P., Xanthopoulos, K. G.: Molecular cloning, sequence, and expression patterns of the human gene encoding CCAAT/ enhancer binding protein alpha (C/EBP alpha). Biochem. Biophys. Res. Commun., 1995, 215(1), 106-113. 
[13] Pabst, T., Mueller, B. U.: Complexity of CEBPA dysregulation in human acute myeloid leukemia. Clin. Cancer Res., 2009, 15(17), 5303-5307.

[14] Pabst, T., Eyholzer, M., Haefliger, S., et al.: Somatic CEBPA mutations are a frequent second event in families with germline CEBPA mutations and familial acute myeloid leukemia. J. Clin. Oncol., 2008, 26(31), 5088-5093.

[15] Wouters, B. J., Löwenberg, B., Erpelinck-Verschueren, C. A., et al.: Double CEBPA mutations, but not single CEBPA mutations, define a subgroup of acute myeloid leukemia with a distinctive gene expression profile that is uniquely associated with a favorable outcome. Blood, 2009, 113(13), 3088-3091.

[16] Bienz, M., Ludwig, M., Leibundgut, E. O., et al.: Risk assessment in patients with acute myeloid leukemia and a normal karyotype. Clin. Cancer Res., 2005, 11(4), 1416-1424.

[17] Stelljes, M., Corbacioglu, A., Schlenk, R. F., et al.: Allogeneic stem cell transplant to eliminate germline mutations in the gene for CCAAT-enhancer-binding protein alpha from hematopoietic cells in a family with AML. Leukemia, 2011, 25(7), 1209-1210.

[18] Tawana, K., Wang, J., Renneville, A., et al.: Disease evolution and outcomes in familial AML with germline CEBPA mutations. Blood, 2015, 126(10), 1214-1223.

[19] Rowley, J. D.: Identification of a translocation with quinacrine fluorescence in a patient with acute leukemia. Ann. Genet., 1973, 16(2), 109-112.

[20] Liew, E., Owen, C.: Familial myelodysplastic syndromes: a review of the literature. Haematologica, 2011, 96(10), 1536-1542.

[21] Churpek, J. E., Lorenz, R., Nedumgottil, S., et al.: Proposal for the clinical detection and management of patients and their family members with familial myelodysplastic syndrome/acute leukemia predisposition syndromes. Leuk. lymphoma, 2013, 54(1), 28-35.

[22] Mangan, J. K., Speck, N. A.: RUNXI mutations in clonal myeloid disorders: from conventional cytogenetics to next generation sequencing, a story 40 years in the making. Crit. Rev. Oncog., 2011, 16(1-2), 77-91.

[23] Preudhomme, C., Renneville, A., Bourdon, V., et al.: High frequency of RUNXI biallelic alteration in acute myeloid leukemia secondary to familial platelet disorder. Blood, 2009, 113(22), 5583-5587.

[24] Yoshimi, A., Toya, T., Kawazu, M., et al.: Recurrent CDC25C mutations drive malignant transformation in FPD/AML. Nat. Commun., 2014, 5, 4770.

[25] Ostergaard, P., Simpson, M. A., Connell, F. C., et al.: Mutations in GATA2 cause primary lymphedema associated with a predisposition to acute myeloid leukemia (Emberger syndrome). Nat. Genet., 2011, 43(10), 929-931.

[26] Hsu, A. P., Sampaio, E. P., Khan, J., et al.: Mutations in GATA2 are associated with the autosomal dominant and sporadic monocytopenia and mycobacterial infection (MonoMAC) syndrome. Blood, 2011, 118(10), 2653-2655.

[27] Dickinson, R. E., Griffin, H., Bigley, V., et al.: Exome sequencing identifies GATA-2 mutation as the cause of dendritic cell, monocyte, B and NK lymphoid deficiency. Blood, 2011, 118(10), 2656-2658

[28] Rodrigues, N. P., Janzen, V., Forkert, R., et al.: Haploinsufficiency of GATA-2 perturbs adult hematopoietic stem-cell homeostasis. Blood, 2005, 106(2), 477-484.
[29] Hyde, R. K., Liu, P. P.: GATA2 mutations lead to MDS and AML. Nat. Genet., 2011, 43(10), 926-927.

[30] Bödör, C., Renneville, A., Smith, M., et al.: Germ-line GATA2 p.THR354MET mutation in familial myelodysplastic syndrome with acquired monosomy 7 and $A S X L 1$ mutation demonstrating rapid onset and poor survival. Haematologica, 2012, 97(6), 890-894

[31] West, R. R., Hsu, A. P., Holland, S. M., et al.: Acquired ASXL1 mutations are common in patients with inherited GATA2 mutations and correlate with myeloid transformation. Haematologica, 2014, 99(2), 276-281.

[32] Green, C. L., Tawana, K., Hills, R. K., et al.: GATA2 mutations in sporadic and familial acute myeloid leukaemia patients with CEBPA mutations. Br. J. Haematol., 2013, 161(5), 701-705.

[33] Kee, Y., D'Andrea, A. D.: Molecular pathogenesis and clinical management of Fanconi anemia. J. Clin. Invest., 2012, 122(11), 3799-3806.

[34] Kirwan, M., Vulliamy, T., Marrone, A., et al.: Defining the pathogenic role of telomerase mutations in myelodysplastic syndrome and acute myeloid leukemia. Hum. Mutat., 2009, 30(11), 15671573.

[35] Olovnikov, A. M.: Telomeres, telomerase, and aging: origin of the theory. Exp. Gerontol., 1996, 31(4), 443-448.

[36] West, A. H., Godley, L. A., Churpek, J. E.: Familial myelodysplastic syndrome/acute leukemia syndromes: a review and utility for translational investigations. Ann. N.Y. Acad. Sci., 2014, 1310, 111-118.

[37] Heiss, N. S., Knight, S. W., Vulliamy, T. J., et al.: X-linked dyskeratosis congenita is caused by mutations in a highly conserved gene with putative nucleolar functions. Nat. Genet., 1998, 19(1), 32-38.

[38] Young, N. S.: Bone marrow failure and the new telomere diseases: practice and research. Hematology, 2012, 17(Suppl. 1), S18S21.

[39] Noris, P., Perrotta, S., Seri, M., et al.: Mutations in ANKRD26 are responsible for a frequent form of inherited thrombocytopenia: analysis of 78 patients from 21 families. Blood, 2011, $117(24), 6673-6680$.

[40] Noetzli, L., Lo, R. W., Lee-Sherick, A. B., et al.: Germline mutations in ETV6 are associated with thrombocytopenia, red cell macrocytosis and predisposition to lymphoblastic leukemia. Nat. Genet., 2015, 47(5), 535-538.

[41] Churpek, J. E., Pyrtel, K., Kanchi, K. L., et al.: Genomic analysis of germ line and somatic variants in familial myelodysplasia/ acute myeloid leukemia. Blood, 2015, 126(22), 2484-2490.

[42] Buijs, A., Poddighe, P., van Wijk, R., et al.: A novel CBFA2 single-nucleotide mutation in familial platelet disorder with propensity to develop myeloid malignancies. Blood, 2001, 98(9), 2856-2858.

[43] Fogarty, P. F., Yamaguchi, H., Wiestner, A., et al.: Late presentation of dyskeratosis congenita as apparently acquired aplastic anaemia due to mutations in telomerase RNA. Lancet, 2003, 362(9396), 1628-1630.

(Bödör Csaba dr., Budapest, Üllői út 26., 1085 e-mail: bodor.csabal@med.semmelweis-univ.hu) 